DOI: https://doi.org/10.47405/mjssh.v5i8.463

\begin{tabular}{|c|c|}
\hline 4 & Malaysian Journal of Social Sciences and Humanities (MJSSH) \\
\hline $\begin{array}{l}\text { Malaysian Journal of } \\
\text { Social sciences and }\end{array}$ & Volume 5, Issue 8, August 2020 \\
\hline (MJ-SSH) & e-ISSN : 2504-8562 \\
\hline & $\begin{array}{l}\text { Journal home page: } \\
\text { www.msocialsciences.com }\end{array}$ \\
\hline
\end{tabular}

\title{
A Study Towards Barriers of Organic Personal Care Consumption Among Indonesian Young Woman
}

\author{
Aqmalia Shafira ${ }^{1}$, Lidia Mayangsari1 \\ ${ }^{1}$ School of Business and Management, Bandung Institute of Technology, Indonesia
}

Correspondence: Aqmalia Shafira (aqmalia_shafira@sbm-itb.ac.id)

\begin{abstract}
In recent decades, consumers begin shifting in the use of healthy products, since people are starting to become aware of the adverse effects caused by synthetic chemicals for health. Several studies that show the global demand for organic products has risen annually, including organic personal care, that has become an inevitable trend. While women are willing to pay more on organic personal care brands, they have doubts about issues related to the ingredients of brands that promise to be all organic. This study aims to measure the influences between barriers towards organic personal care consumption among 400 young women in Jabodetabek and Bandung with the use of Innovation Resistance Theory (IRT). The research was conducted using questionnaires and analyzed using Confirmatory Factor Analysis, with SmartPLS Software. The results indicate that usage barrier, value barrier, tradition barrier have positively and significantly affected organic personal care products consumption, except for risk barriers and image barriers which have insignificant effects. These findings might be useful to create business strategies for organic personal care SMEs in Indonesia, by taking more attention towards the indicator aspect on usage barriers, value barriers and tradition barriers.
\end{abstract}

Keywords: barriers, innovation resistance theory organic, personal care products

\section{Introduction}

In recent decades, additives have been used to replace costly natural ingredients that make cosmetics affordable and commonly used. Nowadays, the movement towards a healthy way of life is growing market preferences and curiosity in predominantly natural products, including personal care. Healthy products are used by people who have an eco-conscious lifestyle and worry about their health (Dimitrova et al., 2009: 1158). Over the time, as the negative effect of synthetic materials on health and environment have increased, more people begin to use natural products which becomes the trend today (Gubitosa, J. Rizzi, V. Fini, P. Cosma, 2019). As a result, there is a switching transformation of consumers' preferences towards organic personal skincare products that are non-toxic and also environmentally friendly. Increasing consumer health awareness would continue to push the growth of organic personal care demand during the forecast period (Transparency Market Research, 2014).

Several results are switching consumer preferences are common across various studies, where women are more involved in organic products than men (Mintel, 2013; Wandel and Bugge, 1997; Davies et al., 1995). More than 50 percent of consumers in the United States, aged 18 to 29, purchased almost only or mainly natural or organic skincare products. When purchasing organic beauty and personal care products, the quality was chosen as the most important criterion by younger consumers (Statista, 2017). 
According to Grandviewresearch.com (2019) the global demand for organic personal care has risen annually, along with growing consumer knowledge of organic personal care products, including skincare, haircare, oral care, body care and cosmetics. In 2018, the market size for this sector was estimated to be USD 13.33 billion and will continue to rise annually.

This is also supported according to Euromonitor International (2015), organic skincare products are on the market with the fastest growth compared to other organic cosmetic products. As in many other regions, organic cosmetics are responsible for an ever-increasing market share in Indonesia, state the market share of organic cosmetics in Indonesia has increased. Indonesia's sales amounted to USD 4.390 million in 2019 of personal care products. Obviously, organic personal care has become an inevitable trend (Nielsen, 2015). While customers are willing to pay more on organic personal care brands, they have doubts about issues related to the ingredients of brands that promise to be all organic. People believe that it is safer not to purchase goods that pretend to use organic ingredients than to buy items that will still make them reconsider the ingredients (Matić and Puh, 2016). Based on L'oreal's research (2018), 75\% of Indonesian women prefer to purchase beauty products brands that are made with organic ingredients, for all cosmetics categories.

The modern cosmetics industry uses a wide range of other chemicals such as parabens, petrochemicals, sodium lauryl sulfate, artificial colors and preservatives. There is no doubt that long-term exposure to such chemicals may cause many health-related problems like cancer, dermatitis and other allergies. Meanwhile, these standards propose "natural" personal care products not to consist of more than 5\% synthetics which, in addition, have to be permitted as an ingredient of "natural" personal care products. The "organic" personal care products - in addition to fulfilling the requirements for natural products also consist of at least $20 \%$ organic ingredients and $95 \%$ of their physically processed agro-ingredients have to be organic (COSMOS-standard, 2013).

Despite organic ingredients becoming a trend some barriers caused by people not using organic personal care products. However, many people are still not concerned and have doubts about purchasing natural products, especially in local brands. As Faber J et al. (2012) stated, the barriers that people face can be distinguished as individual (internal) barriers eg. socio-psychological factors, physiological characteristics and demographic barriers and societal (external) barriers eg.cultural, economic and institutional barriers. For instance, barriers are a part of the thing that can affect purchase intentions. Results of certain Global Health Science Research studies about factors limiting the purchasing of organic products identified factors limited buyers, such as availability, price, quality, and knowledge (Calverley, 2005; Alberta Government, 2006). The result of this research is expected to be able to help local organic personal care SMEs to measure these consumption barriers in order to improve business strategies based on consumer's specific needs and requirements.

\section{Literature Review}

\section{Organic Personal Care Product Consumption}

Consumer habits are related to the society, family, climate and economic reality of consumers. According to Solomon (2002), people purchase a product because of its value, and not because of what it can do. A commodity serves more for the user than its physiological role, such as personal care. Consumers refer to the use of organic goods, their family health, environmental issues, and protection as deciding factors (Darolt, 2004; Lombardi et al., 2007). Grunert (2002) specifically says that after the purchase, preparation and buying, the understanding of food quality takes place. Consumers should develop a concept known as an anticipated price, to take their decisions at the time of purchase. Nevertheless, quality is typically composed of two elements: intrinsic quality and extrinsic quality. Intrinsic quality defined as those qualities which the user does not explicitly perceive, coupled with instruments such as labels and certifications. Of example, the absence of chemicals, chemical residues and the importance of personal care are considered intrinsic features of the product. Extrinsic quality, in effect, is defined as those attributes which the user quickly perceives, i.e. observable, such as colour, appearance, size, shape and price. 


\section{Organic Personal Care Product Consumption Barriers}

Barriers are a part of the thing that affects people's purchase intentions. Ajzen (2005) describes that behaviour will become evident if the person regulates all of the variables that play a role in whether to behave or not. Barriers or customer resistance to any new product can consist of both a functional and psychological. Consumers face functional barriers when they see significant changes due to the adoption of a new product, while psychological barriers arise as a result of conflict with the consumer 's prior belief (Ram \& Sheth, 1989). This research has applied the Innovation Resistance Theory (IRT) paradigm to a thorough explanation of the obstacles faced by consumers to the use and consumption behaviour of organic personal care products. Based on Kuswah (2019), innovation resistance theory has proposed three functional barriers, i.e., usage, value, and risk barriers, and two psychological barriers, namely tradition barriers and image barriers. However, there is a lack of research that provides a detailed view of the barriers faced by consumers in the context of organic personal care in Indonesia. Furthermore, this research helps stakeholders to understand barriers in the context of organic personal care.

\section{a) Usage Barriers}

Buder et al. (2014) found that the reason customers are not purchasing organic goods is the product's availability. Sandalidou et al. (2002), concluded that the lack of consumer awareness about organic products can also be caused by lack of marketing campaigns and information that can be accessed by customers. Barriers, such as limited range of products, availability, and limited information are closely connected to purchase intentions.

\section{b) Value Barriers}

According to Ram and Sheth (1989), the value barrier refers to the performance of innovation, and the monetary value, if the innovation does not achieve expected performance-to-price relative to alternatives, it is not worthwhile for consumers to change their way of consumption. As a consequence, in organic personal care, high costs and additional time are the biggest obstacles due to gaps in value with non-organic personal care.

\section{c) Risk Barriers}

Market penetration refers to brand exploration and identification of product characteristics. The characteristics of the organic product, such as nutritional ingredients, whether the product is certified organic or not, manufactured or imported domestically, country of origin, labelling details including the expiry date. (Bravo et al., 2013). Rana Bhat (2008) advocated that certification would help differentiate organic products from other products and can be useful in promoting organically grown goods on the market.

\section{d) Tradition Barriers}

A customer satisfied enough with the non-organic product that is available in the market and may lack the necessary information to switch from non-organic products to organic products (Botonaki et al., 2006). Their satisfaction with the non-organic product and lack of knowledge may become obstacles not to purchase organic personal care items for consumers.

\section{e) Image Barriers}

According to Torres-Ruiz et al (2018), image barrier refers to the overall image of this organic product in general, and some customers can't distinguish the differentiation between the non-organic personal care and the organic personal care. This statement is also supported by Misra \& Singh (2016), that people can be doubtful or even do not trust the quality of organic personal care in the market. 


\section{Conceptual Framework and Hypotheses}

This research is using the innovation resistance theory as the framework model, developed by Kuswah (2019), shown in Figure 1. The relationships between the variables are as follows: usage barriers, value barriers, risk barriers, tradition barriers, and image barriers can affect the purchase intention of organic personal care products.

Figure 1: Conceptual Framework

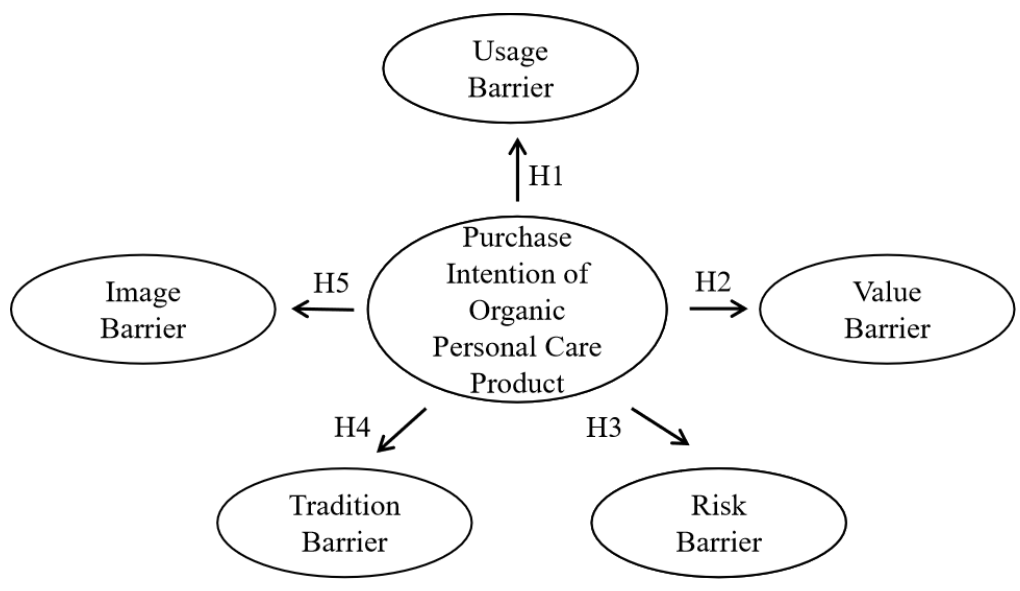

Based on the literature review and conceptual framework, the hypotheses are:

H1 = Usage barriers have a positive influence towards barriers of organic personal care consumption

$\mathrm{H} 2=$ Value barriers have a positive influence towards barriers of organic personal care consumption

H3 = Risk barriers have a positive influence towards barriers of organic personal care consumption

H4 = Tradition barriers have positive influence towards barriers of organic personal care consumption

H5 = Image barriers have a positive influence towards barriers of organic personal care consumption

\section{Methodology}

\section{Research Design}

The researcher used a quantitative method, and developed a questionnaire design that will be used to collect respondents data and analyze data collection using modelling of the structural equation. The data collected by survey using an online questionnaire that will be used to assess the barriers of organic personal care consumption.

\section{Population}

This study's population is Indonesian women that ranging from 18-29 years old focused lived in Jabodetabek and Bandung as a metropolitan city that has a tendency to know about organic products but rarely consumed organic personal care products.

\section{Sampling Procedures}

This study uses non-probability sampling technique, with a purposive sampling method. Purposive sample is a form of nonprobability sample, often referred to as a judgmental or expert sample. A 
purposive sample 's main goal is to generate a sample which can reasonably be believed to be representative of the population (Lavrakas, 2008). This study's population is Indonesian women that ranging from 18-29 years old focused lived in Jabodetabek and Bandung as a metropolitan city that has a tendency to know about organic products but rarely consumed organic personal care products.

The sample size is the number of respondents who participated in the study (Malhotra, 2015). The researcher referred to Malhotra (2010) with a minimum sample of 200 until 400 respondents, using a 5 percent margin error with a 95 percent confidence level. The sample size of this study is 400 women who were chosen for this study.

\section{Data Collection}

This study questionnaire consisted of several parts. The first part is socio-demographic data about respondents that consisted of gender, age, current domicile, and occupation. Entering the main part, the first main part is to assess the independent variable which is barriers of organic personal care and the purchase intention as the dependent variable. All questions in the questionnaire were measured with a 5-point Likert type scale ranging from 1 (strongly disagree) to 5 (strongly agree), by using Bahasa Indonesia to make the respondent easily understand the question.

This study used an online questionnaire to collect the data from respondents as the key method or instrument. Since the questionnaire's limitation area, the respondent is in Bandung, Indonesia the Bahasa Indonesia is used for the item questions. The researcher has used a Google Form to create a questionnaire online. As for the communication, the researcher distributed the questionnaire via Social Media Line via personal chat and Instagram social media via direct message. The pilot test followed with a validity and reliability check also carried out before data collection began.

Usage barriers are measured by three items, one indicator of limited variety by Seyed Abolhasan Sadati, et al (2010), and two indicators of availability Nandi, et al. (2017). Value barriers are measured by three items, with high price indicators from Torres-Ruiz, Vega-Zamora and Parras-Rosa (2018), Krishna and Balasubramanian (2018), Jannsen (2018). Risk barriers are measured by three items, with the indicators lack of trust to stakeholders and doubt regarding certification by Krishna and Balasubramanian (2018). Tradition barriers is measured by three items, with satisfaction with nonorganic products one by Nandi, et al. (2017), and one by Torres-Ruiz, Vega-Zamora and Parras-Rosa (2018), and one indicator lack of knowledge by Hoppe, Vieira and Barcellos, (2013). Image barriers are measured with three items, with the indicators of perceived skepticism against organic products by von Meyer-Höfer, et al. (2015), Nandi, et al (2017), and Misra \& Singh (2016). Purchase intentions are measured with three items by Kuswah (2019).

Table 1. Distribution of Respondent Demographics

\begin{tabular}{ccc}
\hline Variable & Category & Frequency (\%) \\
\hline Gender & Female & $400(100 \%)$ \\
\multirow{2}{*}{ Domicile } & Jabodetabek & $203(50,6 \%)$ \\
& Bandung & $198(49,4 \%)$ \\
Level of Education & Senior High School & $357(89.25 \%)$ \\
& Bachelor Degree & $27(6,75 \%)$ \\
& Associate Degree & $12(3 \%)$ \\
& Master Degree & $4(1 \%)$ \\
& College Student & $357(89 \%)$ \\
\hline
\end{tabular}




\begin{tabular}{ccc}
\hline & Employee & $26(6.5 \%)$ \\
Freelancer & $15(3.75 \%)$ \\
Entrepreneur & $7(1,75 \%)$ \\
Intern & $2(0.5 \%)$ \\
Housewife & Never & $4(1 \%)$ \\
Frequency on Purchasing & Once in $>6$ months & $47(11,75)$ \\
Organic Personal Care & Once in 6 months & $123(30,75 \%)$ \\
Products & Once in 3 months & $30(7,5 \%)$ \\
$\begin{array}{c}\text { Store Preferences of } \\
\text { Purchasing Organic }\end{array}$ & Never & $151(37.75 \%)$ \\
Personal Care Products & Online Store & $47(11,75)$ \\
& Offline Store & $71(17,75 \%)$ \\
\hline
\end{tabular}

\section{Data Analysis}

The analysis technique used in this study is confirmatory factor analysis confirmatory (CFA), which is a multivariate analysis method that can be used to test or confirm whether a model measurement is built according to the one hypothesized (Hair et al., 2009). There are several steps needed to be conducted to process the data, using SmartPLS 3.0, which started with developing a conceptual model and processing the data by using PLS algorithm and bootstrapping.

\section{Results}

\section{Convergent Validity}

Convergent validity extent of which indicators of a specific construct. The measurements to verify convergent validity used in CFA are Factor Loading, Composite Reliability, and Average Variance Extracted (Hair et al., 2009).

\section{Factor Loading}

Convergent validity will be fulfilled if the factor loading value of each item $>0.5$, and if $>0,7$ that value is the ideal value (Hair et al., 2009).

Based on table 2 it shows that all of these indicators convergent validity because their values are $>0.5$, it means the indicators are passed the convergent validity and can be continued to the next testing. 
Malaysian Journal of Social Sciences and Humanities (MJSSH), Volume 5, Issue 8, (page 48 - 59), 2020

DOI: https://doi.org/10.47405/mjssh.v5i8.463

Table 2. Factor Loading

\begin{tabular}{|c|c|c|c|c|}
\hline Construct & Code & Item & $\begin{array}{l}\text { Factor } \\
\text { Loading }\end{array}$ & Validity \\
\hline \multirow{4}{*}{$\begin{array}{l}\text { Usage } \\
\text { Barrier }\end{array}$} & UB1 & $\begin{array}{l}\text { The variety or range of organic personal care } \\
\text { products is poor }\end{array}$ & 0.911 & Valid \\
\hline & UB2 & $\begin{array}{l}\text { The reason I'm not purchasing organic personal care } \\
\text { because } \\
\text { it's unavailable in the market }\end{array}$ & 0.919 & Valid \\
\hline & UB3 & It takes me too much trouble in search of organics & 0.85 & Valid \\
\hline & VB1 & $\begin{array}{l}\text { I feel that organic products are more expensive than } \\
\text { conventional products }\end{array}$ & 0.861 & Valid \\
\hline \multirow[t]{3}{*}{$\begin{array}{l}\text { Value } \\
\text { Barrier }\end{array}$} & VB2 & $\begin{array}{l}\text { I prefer buying organic personal care products when } \\
\text { price discounts are offered }\end{array}$ & 0.874 & Valid \\
\hline & VB3 & $\begin{array}{l}\text { When there is a special offer price for organic } \\
\text { products, I tend to buy these organic products. }\end{array}$ & 0.851 & Valid \\
\hline & $\mathrm{RB} 1$ & $\begin{array}{l}\text { I need to know the brand's reputation well before } \\
\text { buying an organic product }\end{array}$ & 0.700 & Valid \\
\hline \multirow[t]{3}{*}{$\begin{array}{l}\text { Risk } \\
\text { Barrier }\end{array}$} & RB2 & $\begin{array}{l}\text { I prefer to buy organic products if I already know } \\
\text { the brand }\end{array}$ & 0.791 & Valid \\
\hline & RB3 & $\begin{array}{l}\text { I would prefer to buy organic personal care } \\
\text { products if I have enough information, regarding } \\
\text { how far is organic }\end{array}$ & 0.820 & Valid \\
\hline & TB1 & $\begin{array}{l}\text { Taste of non-organic products are better than } \\
\text { organic personal care products }\end{array}$ & 0.916 & Valid \\
\hline \multirow{3}{*}{$\begin{array}{l}\text { Tradition } \\
\text { Barrier }\end{array}$} & TB2 & The non-organic product is good enough for me & 0.893 & Valid \\
\hline & TB3 & $\begin{array}{l}\text { Compared to most other people, I know less about } \\
\text { organic body care products }\end{array}$ & 0.551 & Valid \\
\hline & IB1 & $\begin{array}{l}\text { I don't think that such products of organic personal } \\
\text { care products really exist }\end{array}$ & 0.716 & Valid \\
\hline \multirow[t]{3}{*}{$\begin{array}{l}\text { Image } \\
\text { Barrier }\end{array}$} & IB2 & $\begin{array}{l}\text { No difference between organic beverages products } \\
\text { and the non-organics }\end{array}$ & 0.865 & Valid \\
\hline & IB3 & $\begin{array}{l}\text { I have doubts about buying organic personal care } \\
\text { products }\end{array}$ & 0.922 & Valid \\
\hline & PI1 & I am happy to buy organic personal care products & 0.844 & Valid \\
\hline \multirow[t]{2}{*}{$\begin{array}{l}\text { Purchase } \\
\text { Intention }\end{array}$} & PI2 & I plan to consume organic personal care products & 0.894 & Valid \\
\hline & PI3 & I would buy organic personal care products & 0.909 & Valid \\
\hline
\end{tabular}




\section{Construct Reliability \& Validity}

To find out the reliability of each construct in this analysis, checking is performed by looking at the importance of each construct's Composite Reliability and Cronbach's Alpha. To be able to achieve good efficacy of reliability, the composite reliability value must be higher than 0.7 , the Cronbach Alpha value must be higher than 0.6 and the AVE value must be or greater than 0.5 (Wong, 2013).

Table 3. Construct Reliability \& Validity

\begin{tabular}{cccc}
\hline & Cronbach's Alpha & Composite Reliability & $\begin{array}{c}\text { Average Variance } \\
\text { Extracted (AVE) }\end{array}$ \\
\hline Usage Barrier & 0.874 & 0.923 & 0.799 \\
Value Barrier & 0.827 & 0.897 & 0.743 \\
Risk Barrier & 0.67 & 0.815 & 0.596 \\
Tradition Barrier & 0.727 & 0.84 & 0.647 \\
Image Barrier & 0.821 & 0.876 & 0.704 \\
Purchase Intention & 0.858 & 0.914 & 0.779 \\
\hline
\end{tabular}

Based on Table 3 it explained that the results of composite testing reliability show good results because the overall latent variable has been reliable because it has a composite reliability value greater than 0.7 . The value indicates that all the indicators are measured when each constructed correctly. Table 5.10 shows that all variables are latent and have a Cronbach's Alpha value above 0.7. Similarly, with the AVE value on research variables have values above 0.5. In conclusion, this research has fulfilled reliability.

\section{Discriminant Validity}

Discriminant validity develops to show that any construction is different from each other. Fornell \& Larcker (1981) states that a correlation between constructs evaluates discriminant validity. The square root of each construct value must be higher than all correlation values of the constructs.

Table 4. Discriminant Validity Fornell-Larcker

\begin{tabular}{ccccccc}
\hline & $\begin{array}{c}\text { Image } \\
\text { Barrier }\end{array}$ & $\begin{array}{c}\text { Purchase } \\
\text { Intention }\end{array}$ & $\begin{array}{c}\text { Risk } \\
\text { Barrier }\end{array}$ & $\begin{array}{c}\text { Tradition } \\
\text { Barrier }\end{array}$ & $\begin{array}{c}\text { Usage } \\
\text { Barrier }\end{array}$ & $\begin{array}{c}\text { Value } \\
\text { Barrier }\end{array}$ \\
\hline Image Barrier & $\mathbf{0 . 8 3 9}$ & & & & & \\
Purchase Intention & -0.041 & $\mathbf{0 . 8 8 3}$ & & & & \\
Risk Barrier & -0.023 & 0.249 & $\mathbf{0 . 7 7 2}$ & & & \\
Tradition Barrier & 0.126 & -0.429 & -0.079 & $\mathbf{0 . 8 0 4}$ & & \\
Usage Barrier & -0.035 & 0.623 & 0.255 & -0.261 & $\mathbf{0 . 8 9 4}$ & \\
Value Barrier & -0.003 & 0.732 & 0.249 & -0.451 & 0.493 & $\mathbf{0 . 8 6 2}$ \\
\hline
\end{tabular}

In table 4 above, each construct's square root value is higher than the other correlation value, indicating that each construct is different from another construct in this study.

\section{Hypotheses Testing and Discussion}

The table 5 shows the significant level of each construct, as a result $\mathrm{H} 1, \mathrm{H} 2, \mathrm{H} 4$ has the p-value less than 0.5 and the $\mathrm{t}$-value is above 1.96. Therefore, $\mathrm{H} 1, \mathrm{H} 2, \mathrm{H} 4$ were accepted. It means, the usage barrier (UB), value barrier (VB), and tradition barrier (TB), has significantly influenced the purchase intention towards organic personal care products. Meanwhile, $\mathrm{H} 3$ and $\mathrm{H} 5$ have p-value above 0.5 so it 
DOI: https://doi.org/10.47405/mjssh.v5i8.463

fails to meet the significant value, and the hypothesis is rejected. It means the risk barrier (RB), and image barrier (IB), do not significantly influence the purchase intention towards organic personal care.

Table 5. Hypothesis Testing Result

\begin{tabular}{llll}
\hline \multicolumn{1}{c}{ Hypothesis } & $\begin{array}{c}\text { T Statistics } \\
(|\mathbf{O} / \mathbf{S T D E V}|)\end{array}$ & P Values & Decision \\
\hline $\begin{array}{l}\text { H1 = Usage barriers have a positive influence } \\
\text { towards barriers of organic personal care } \\
\text { consumption }\end{array}$ & 8.338 & 0.000 & Accepted \\
$\begin{array}{l}\text { H2 = Value barriers have a positive influence } \\
\text { towards barriers of organic personal care } \\
\text { consumption }\end{array}$ & 12.458 & 0.000 & Accepted \\
$\begin{array}{l}\text { H3 }=\text { Risk barriers have a positive influence } \\
\text { towards barriers of organic personal care } \\
\text { consumption }\end{array}$ & & & \\
$\begin{array}{l}\text { H4 }=.745 \\
\text { influence towards barriers of organic personal } \\
\text { care consumption }\end{array}$ & & 0.457 & Rejected \\
$\begin{array}{l}\text { H5 }=\text { Image barriers have a positive influence } \\
\text { towards barriers of organic personal care } \\
\text { consumption }\end{array}$ & & & \\
\hline
\end{tabular}

The researchers want to measure the influence of usage barriers, value barriers, risk barriers, tradition barriers, and image barriers in purchasing organic personal care products among Indonesian women aged 18-29 years old. From the confirmatory factor analysis, we can confirm a specific relationship for each construct. The first one from $\mathrm{H} 1$, usage barriers have a positive influence towards barriers of organic personal care consumption. As Nandi, et al. (2016), state that the factor of limited variety or poor range of organic products, and it's unavailability in the market can be the reason why customers are not purchasing organic products. The hypothesis from $\mathrm{H} 1$ is rejected with $8.338 \mathrm{t}$-value, and 0.000 p-value. It means that the respondents find trouble in search of organics based on the availability of these items on the market.

From $\mathrm{H} 2$, value barriers have a positive influence on barriers of organic personal care consumption. Supported by Kotler's statement (2009), that price is the sum value of products and services. Price is the amount of all values provided by consumers, to benefit from using a product. The respondents feel the price for organic products is more expensive, so they feel the difference in price with non-organic is one of the obstacles to purchasing organic personal care products. Besides, the respondents will be more interested in buying when there are discounts or special offers. The hypothesis from $\mathrm{H} 2$ is accepted with $12.458 \mathrm{t}$-value, and $0.000 \mathrm{p}$-value. It means that the respondents feel that the high price of organic personal care products is one of the main barriers to purchasing organic personal care products.

The next one is $\mathrm{H} 3$, that risk barriers have a positive influence on barriers to organic personal care consumption. Risk barriers can appear from lack of trust to the stakeholders and also doubt regarding the product's certification (Khrisna and Balasubramanian, 2018). In this research, the respondents need to know the brand's reputation well before buying an organic product, and should have enough information about the organic products. But in the CFA result, the hypothesis is rejected because it has 0.745 as the $t$ value and $0.457 \mathrm{p}$-value. It means that the risk barriers are not significantly influenced barriers of organic personal care consumption. 
From H4, tradition barriers have positive influence towards barriers of organic personal care consumption. From H4, tradition barriers have a positive influence towards barriers of organic personal care consumption. The indicator of traditional barriers is satisfaction with conventional products (Torres-Ruiz, Vega-Zamora and Parras-Rosa, 2018). It means that the respondents agree to not consuming the organic personal care products because the non-organic personal care products are already good enough for them. Likewise, tradition barriers also include the lack of knowledge about the organic personal care products itself (Hoppe, Vieira and Barcellos, 2013). This is related with the research that the respondents know less about organic personal care products. This statement supported with $\mathrm{H} 4$ accepted with 3.357 as the t-value and 0.001 as the p-value. It means, tradition barriers are significantly influenced barriers of organic personal care consumption.

Meanwhile for the discussion of H5, image barriers have a positive influence towards barriers of organic personal care consumption. Image barriers can appear because the customers are skeptical against the organic personal care products (Misra, 2016). They have doubts regarding organic products consumption, and feel that there are no differences between the organic products and non-organic products. But, in this research the hypothesis is rejected with 0.345 as the t-value and 0.730 as the pvalue. The respondents know the differentiation and the benefits between organic and non-organic personal care products. Therefore, image barriers do not significantly influence the barriers of organic personal care consumption.

\section{Conclusion and Recommendations}

The result of these research shows that using innovation resistance theory (IRT) not all of the barriers are having significant relationship towards purchasing organic personal care products. In IRT there are five barriers, which consists of usage barriers, value barriers, risk barriers, tradition barriers, and image barriers. Using the CFA method, it is obtained that from those five barriers, only three barriers significantly impact the purchase intention of organic personal care products. The usage barrier, value barrier, and tradition barrier are found to have a positive influence to barriers of organic personal care consumption. Meanwhile, the risk barrier and image barrier are not showing the positive influence on barriers to organic personal care consumption.

Based on the research results above, there are recommendations. For organic personal care SMEs, especially those who open their businesses in the Jabodetabek and Bandung, it is recommended to pay attention to indicators of inhibiting variables which most influences the take intention of consumers to buy organic personal care products. Likewise, overcoming the obstacles that consumers feel are not to purchase their products also produces a good marketing strategy for the business to increase the sales.

This study has limitations on the scale of the population that is difficult to identify which is people that have a tendency to know organic products but rarely purchase organic personal care products, so the researcher ended up using the intersection of required characteristics and used purposive sampling. This study only focuses on barriers and purchase intention variables. The industry of this study also only limited on organic personal care products. For further future research, the researcher can broaden the topic outside of organic personal care brands. There is also a good chance for researchers to test other variables other than barriers that have a relationship with organic personal care consumption.

\section{References}

Aguirre, J. A. (2007). The farmer's market organic consumer of Costa Rica. British Food Journal. Ajzen, I. (2005). Attitudes, personality, and behavior. McGraw-Hill Education (UK).

Botonaki, A., Polymeros, K., Tsakiridou, E., \& Mattas, K. (2006). The role of food quality certification on consumers' food choices. British Food Journal.

Bravo, C. P., Cordts, A., Schulze, B., \& Spiller, A. (2013). Assessing determinants of organic food consumption using data from the German National Nutrition Survey II. Food quality and Preference, 28(1), 60-70. 
Buder, F., Feldmann, C., \& Hamm, U. (2014). Why regular buyers of organic food still buy many conventional products. British Food Journal.

Cosmos-standard (2013). Cosmetics organic and natural standard. [electronic] Available via:http://www.cosmos-standard.org/docs/COSMOS-standard-v2-21102013.pdf (Accessed on February 2020).

Darolt, M. R. (2001), The role of the consumer in the organic products market. Agroecology Today, v. 2, 8-9.

Davies, A., Titterington, A. J., \& Cochrane, C. (1995). Who buys organic food?. British Food Journal.

Dimitrova, V., Kaneva, M., \& Gallucci, T. (2009). Customer knowledge management in the natural cosmetics industry. Industrial Management \& Data Systems.

Euromonitor International (2015). (https://www.euromonitor.com/skin-care. (Accessed on February 2020).

Fornell, C., \& Larcker, D. F. (1981). Structural equation models with unobservable variables and measurement error: Algebra and statistics.

Grunert, S. C., \& Juhl, H. J. (1995). Values, environmental attitudes, and buying of organic foods. Journal of economic psychology, 16(1), 39-62.

Gubitosa, J., Rizzi, V., Fini, P., \& Cosma, P. (2019). Hair Care Cosmetics: From Traditional Shampoo to Solid Clay and Herbal Shampoo, A Review. Cosmetics, 6(1), 13.

Hair, J. F., \& Black, W. C. (2009). Multivariate data analysis (7th International Economy Edition).

Hoppe, A., Vieira, L. M., \& Barcellos, M. D. D. (2013). Consumer behaviour towards organic food in porto alegre: an application of the theory of planned behaviour. Revista de Economia $e$ Sociologia Rural, 51(1), 69-90.

Krishna, R. and Balasubramanian, P., 2018. The significance of factors influencing consumer behaviour towards organic food products in Kochi. International Journal of Pure and Applied Mathematics, $119(12), 2641-2665$.

Kushwah, S., Dhir, A., \& Sagar, M. (2019). Understanding consumer resistance to the consumption of organic food. A study of ethical consumption, purchasing, and choice behaviour. Food Quality and Preference, 77, 1-14.

Kushwah, S., Dhir, A., Sagar, M., \& Gupta, B. (2019). Determinants of organic food consumption. A systematic literature review on motives and barriers. Appetite, 143, 104402.

Lavrakas, P. J. (2008). Encyclopedia of survey research methods. Sage Publications.

Magnusson, M. K., Arvola, A., Hursti, U. K. K., Åberg, L., \& Sjödén, P. O. (2001). Attitudes towards organic foods among Swedish consumers. British food journal.

Malhotra, N.K. (2010). Marketing Research: An Applied Orientation. 6th ed. Upper Saddle River, NJ: Pearson Education.

Malhotra, N.K. (2015). Essentials of Marketing Research: A Hands-on Orientation. Essex, England: Pearson Education.

Mandese, J. (1991). New study finds green confusion. Advertising Age, 62(45), 1-56.

Matić, M., \& Puh, B. (2015). Exploring consumers' purchase attitudes towards natural cosmetics. Ekonomska misao i praksa: časopis Sveučilista u Dubrovniku, 24(2), 433-448.

Mintel (2013). Natural and Organic Toiletries-UK. [electronic] Available via:http://academic.mintel.com/display/640063/ (Accessed on February 2020)

Misra, R., \& Singh, D. (2016). An analysis of factors affecting growth of organic food. British Food Journal.

Nandi, R., Bokelmann, W., Gowdru, N.V. and Dias, G., 2017. Factors influencing consumers' willingness to pay for organic fruits and vegetables: Empirical evidence from a consumer survey in India. Journal of Food Products Marketing, 23(4), 430-451.

Neilsen. (2015). Looking to Achieve New Product Success. Nielsen Global New Product Innovation Report June.

Philip, K., \& Keller, K. L. (2009). Marketing management thirteenth Edition.

Ram, S. and Sheth, J.N., 1989. Consumer resistance to innovations: the marketing problem and its solutions. Journal of consumer marketing.

Rana Bhat, B., 2008. Opportunitiy and Challenges of Organic Certification System in Nepal. In Proceedings of International Workshop on Opportunities and Challenges of Organic Production and Marketing in South Asia, NPG, Kathmandu, Nepal (pp. 104-108). 
DOI: https://doi.org/10.47405/mjssh.v5i8.463

Sadati, S.A., Sadati, S.A., Fami, H.S. and Del, P.T.T., 2010. Survey consumer attitude toward barriers of organic products (op) in Iran: A case study in Gorgan City. World Applied Sciences Journal, 8(11), 1298-1303.

Sandalidou, E., Baourakis, G. and Siskos, Y., 2002. Customers' perspectives on the quality of organic olive oil in Greece. British Food Journal.

Solomon, M.R. (2002), Consumer Behaviour, 2nd ed., Financial Times Prentice-Hall, Harlow

Statista (2017). Cosmetics Industry - Statistics and Facts. https://www.statista.com/topics/3137/cosmetics-industry/. (Accessed on February 2020).

Torres-Ruiz, F.J., Vega-Zamora, M. and Parras-Rosa, M., 2018. False barriers in the purchase of organic foods. The case of extra virgin olive oil in Spain. Sustainability, 10(2), 4610

Transparency Market Research (2014). https://www.transparencymarketresearch.com/organicpersonal-care-products.html. (Accessed on February 2020).

von Meyer-Höfer, M., Olea-Jaik, E., Padilla-Bravo, C.A. and Spiller, A., 2015. Mature and emerging organic markets: Modelling consumer attitude and behaviour with partial least square approach. Journal of Food Products Marketing, 21(6), 626-653.

Wong, K.K.K., 2013. Partial least squares structural equation modeling (PLS-SEM) techniques using SmartPLS. Marketing Bulletin, 24(1), 1-32. 